\title{
THE METHOD OF SILIUS ITALICUS
}

By R. B. Steele

Silius went to his work with the training of an orator, and attempted to infuse poetical coloring into an historical narrative. As an indication of his method we shall consider the following elements:
I. The Historical
II. The Oratorical
III. Adaptations of Lucan's Pharsalia
IV. Metrical Technique

\section{THE HISTORICAL \\ 1. SCENES FROM LIVY}

The foundation of the Punica is the history of Livy. Both works show us the Second Punic War from Saguntum to Zama. But had Silius not been able to vary in some respects from the narrative of Livy, there would not have been any justification for his work. To justify his own work he reproduces the same scenes with different figures, and with such changes in coloring as were suitable for a poetical, rather than an historical, delineation. Mago is a good illustration of a change of figures. Historically considered, Hannibal is the overshadowing figure in the Second Punic War, but Silius makes Mago almost his equal. As he puts it (iii. 240): fratrem spirat in armis. This position is also well indicated in vi. 60:

\section{.... agit asper acerba}

Nunc Mago attonitos, nunc arduus Hannibal hasta,

the two men differing only as asper differs from arduus. It is to Mago that Silius ascribes the invention of the scheme of tying fagots to the horns of the oxen (vii. $329 \mathrm{ff}$.) and, according to $\mathrm{x}$. 382 , it is he, instead of Maharbal (Livy xxii. 51.2), who advises action on the part of Hannibal. As a justification for this see iv. 562:

Hinc Mago, hinc saevus pariter videre Maharbal. 
When the rings were shown to the Carthaginian senate it is Mago (xi. $545 \mathrm{ff}$.) instead of Himilcho (Livy xxiii. 12. 6), who taunts Hanno. Yet both writers give practically the same speech:

Iamne tibi dextras inceptaque nostra probamus?

Anne iterum Hannibalem dedi placet?

for which Livy has Etiam nunc poenitet belli suscepti adversus Romanos? Iube dedi Hannibalem.

The desire for variation in color is noticeable in some scenes where Silius develops something but lightly touched on by Livy. According to Livy (xxiii. 47.6), when the Romans were besieging Capua, a Campanian, Taurea by name, challenged his rival, Claudius Asellus, to mortal combat. For a time their charges were futile, and then Claudius suggested that they turn their horses down into a hollow road, but Taurea, verbis ferocior quam re Minime sis, inquit, Cantherium in fossam; quae vox in rusticum inde proverbium prodita est. Claudius, after he had ridden the length of the road, returned into camp. However, Livy found in certain annals the statement that he chased Taurea into Capua, and, entering at the open gate, rode through the entire city. It is this addendum which is developed by Silius (xiii. $173 \mathrm{ff}$.). Livy (xxii. 52.6) says certain writers state that the body of Paulus was discovered and buried after the battle at Cannae. The scene is pictured at length by Silius (x. $505 \mathrm{ff}$.). When the dead Paulus is drawn from a heap of the slain, there is, in the words heu quis erat a suggestion that he was another Hector; see Vergil Aeneid ii. 274: hei mihi, qualis erat! Special honors of burial are shown, with Hannibal as decoris laudator. A better illustration of varied coloring is the account of the departure of Hannibal from Italy, and the actions leading up to the battle of Zama. The central facts are the same as in Livy, but the accessories are very different. Livy freely develops the oratorical elements, while Silius assigns the talking to the gods. He presents the battle itself as parallel to the contest of Aeneas and Turnus, just as if Vergil had fixed the form in accordance with which historical actions should be carried on.

As a fair indication of the difference in method of treatment, we shall present a few scenes, fact or fancy as the case may be, as portrayed by both. 
1. The serpent (iii. 170-213): Livy (xxi. 22. 6 ff.). - Livy shows a serpent mira magnitudine, while Silius is more exact:

Attollensque caput nimbosis montibus aequat, placing it on an equality with the celebrated snake killed by the army of Regulus (vi. 221):

At nemus arrectae et procera cacumina saltus

Exsuperant cristae.

The last two words show that he had in mind the account of Vergil (Aeneid ii. 206). See also 198: neque enim sopor ille, also slightly changed from Vergil (Aeneid iii. 173). In addition to the color from the Vergilian reminiscences, Silius gets more by the insertion of two fully developed similes.

2. Crossing the Rhone (iii. 442-65): Livy (xxi. 27-28).-Silius concerns himself with the Rhone rather than with the crossing, though some verbal resemblances show that both writers were looking at the same picture. Silius has iniecta tellure for humo iniecta, ducere in altum for in amnem porrexerunt, paulatim . . . . resolutis ... vinculis for extemplo resolutis . . . vinculis. Compare the historian's words, equorum magna pars nantes loris a puppibus rahebantur, with those of the poet:

Fluminea sonipes religatus ducitur alno.

A still better comparison is the fact of Livy about the elephants: excidere etiam quidam in flumen, with the fancy

At gregis illapsu fremebundo territus acris

Expavit moles Rhodanus stagnisque refusis

Torsit harenoso minitantia murmura fundo.

3. The Alps (iii. 47y-99): Livy (xxi. 32. 6-8).-These two accounts, as the preceding, have certain verbal resemblances, as conspectae propius .... Alpes for ex propinquo visa montium altitudo, and cuncta gelu tecta for omnia rigentia gelu. Livy pictures the mountains as they appeared to the men gradually turning their gaze from the base to the summit. The account of Silius is general and unemotional, for his readers, and not as if for the soldiers. In the midst of his description he introduces a simile borrowed from Vergil, and closes with a reference to Hercules.

4. Crossing the Apennines and the marshes of the Arno (iv. 799-61): Livy (xxi. 56; xxii. 2).-According to Livy the storm which burst 
on the army of Hannibal when it was crossing the Apennines surpassed in fury anything it had met in crossing the Alps. The crossing of the marshes a little later is set forth with the same heightened color. Silius reads as if the two movements were in reality but one, and the mountains he pictures per se, without reference to their effect on the men:

Condiderat nix alta trabes, et vertice celso

Canus apex structa surgebat ad astra pruina.

The lack of the personal element is also noticeable in what he says of the marshes, which he portrays only with reference to its effect on Hannibal, the single touch in Livy, altero oculo capitur, being expanded into

manante per ora / perque genas oculo.

5. The battle of Trasumene (iv. 823-vi. 13): Livy (xxii. 4 ff.).The account of the poet is about seven times as long as that of the historian, and still longer if we should include some associated matter. However, the greater length is partly accounted for by the fact that Silius has incorporated a series of prodigies and the admonitions to Flaminius, which, as Livy tells us, preceded the battle. Livy times the first movement in four words, vixdum satis certa luce. Silius has (v. $24 \mathrm{ff}$.):

Et iam curriculo nigram nox roscida metam Stringebat, nec se thalamis Tithonia coniux Protulerat stabatque nitens in limine primo, Cum minus abnuerit noctem desisse viator, Quam coepisse diem.

Seneca (Ludus ii.) had already ridiculed a similar statement, but his arraignment was either unknown to, or lost on, Silius. There is the same exuberance in speaking of the mist, orta ex lacu nebula campo quam montibus densior sederat. Here also Silius lays on the colors (v. 34 ff.):

Tum super ipse lacus, densam caligine caeca

Exhalans nebulam, late corruperat omnem

Prospectum miseris, atque atrae noctis amictu

Squalebat pressum picea inter nubila caelum.

The description of the battle is cast in heroic mold, and we can scarcely see it for the men who take part. As if it were an introductory scene 
for Cannae, the gods do not participate, but are merely onlookers, as Juno (v. 206):

Sola, Apennini residens in vertice, diras

Expectat caedes immiti pectore Iuno.

Prominence is given to the deeds and death of Sychaeus, to whom (iv. 825) was assigned the guarding of the pass by which the Romans entered. In contrast with this portrayal is the part Silius assigns to the Insubrian horseman Ducarius, to whom Livy ascribes the glory of killing Flaminius. As if this would be a lowering of the dignity of a Roman consul, Silius says, tunc undique fusis obruitur telis (cf. Vergil Aeneid ii. 410 telis . . . obruimur), and the dead consul is covered by a mass of Romans slain. In spite of the wide difference between the account of Livy and that of Silius, the latter made use of the former, as is shown by such passages as Poenus nunc occupet altos $\mid$ Arreti muros and postremo ad moenia Romae|illaesus contendat iter, which are variations of Livy xxii. 3. 9-10. The one sentence in which the historian describes the earthquake (ibid. 5. 8) is expanded to sixteen lines (v. 611-26), closing with an adaptation and a poetic touch:

Ac super haec reflui pugnarunt montibus amnes,

Et retro fluctus torsit mare. Monte relicto

Apenninicolae fugere ad litora Fauni.

6. The battle of Cannae (viii. 622-x. 386): Livy (xxii. 44-49).This passage is not only the center but also the culmination of the work of Silius. The personal phases of the description are the same as in the preceding section, but following the example of Vergil, Silius pictures the places which sent forces to the field. But more than this (ix. 288) discordia demens intravit caelo superosque ad bella coegit, and they left the sky and descended to the fray, just as if it were a far-away time when both gods and men engaged in battle. The coming of a great disaster was announced by portents, especially (viii. 637):

Regnorum eversor, rubuit letale cometes.

Still, the facts, so far as given, are set forth with an eye to Livy. Notice (x. 273) cape, quaeso, hunc, unice rerum fessarum, cape cornipidem, where Livy (xxii. 49.7) has only cape hunc equum. Other 
statements are nearer the historical text: quod . . . . non desperaverit urbi (x. 629): quod de re publica non desperavisset; and ibid. 655:

Damnatis Siculas longe meritare oras

Impositum, donec Latio decederet hostis.

Compare with this Livy (xxiii. 25. 7): In Siciliam eos traduci atque ibi militare, donec in Italiam bellum esset, placuit.

\section{QUASI-HISTORICAL}

Three other episodes will be presented here, as they may be considered quasi-historical. Even if not actual events, one, at least, had a historical basis, and the others have their place in literary history.

1. The story of Marus (vi. 62-551).--Serranus, the son of Regulus, wounded at the battle of Trasumene, finds his way to the home of Marus, an old soldier who had served under Regulus. He tenderly cares for the wounded man and recounts the killing of a wonderful snake in Africa. The story brings from Serranus the statement that, had Regulus lived, neither Trebia nor Trasumene would be famous for a Roman defeat. With this as a suggestion, Marus describes the return of Regulus to Rome, and his going back to Africa (ibid. 299550). Disaster followed the death of the serpent, as in the case of Cadmus. Silius had his eye on Ovid (Metam. iii. $31 \mathrm{ff}$.), as is shown by a word here and there: extulit caput (1. 186), curvamine (1. 259), donec (1. 279), and the adaptation spiris ingentibus artae (1. 194), for longis amplexibus illos (Metam. iii. 48). Mingled with the main story are reminiscences of Vergil, as in stating the size of the snake (l. 221; Aeneid ii. 206), and the fear of the soldiers (ll. $188 \mathrm{ff}$.$) :$

Diffugimus tenuemque metu conamur anheli

Tollere clamorem frustra; . . . . .

Occulit, infandum si posset fallere monstrum.

This combines widely separated parts, the first from Aeneid vi. $491 \mathrm{ff}$., of the dead Greek heroes, and of Dido (ibid. iv. 85):

Detinet, infandum si fallere possit amorem.

The introduction of the words of Marcia into the account of Regulus adds a deeper personal interest to the story, which, in the main parts, expands the items mentioned by Horace (Odes iii. $5.41 \mathrm{ff}$.), of which there is an adaptation (ii. $340 \mathrm{ff}$.). 
2. Hannibal and Himilche (iii. 61-157; iv. 763-821). -The wife of Hannibal was from the Spanish town Castulo (1. 99; Livy xxiv. 41. 7). In the section just considered Silius tried to vary the monotony of historical narrative by the introduction of a hero of the First Punic War, with variety added by the part taken by Marcia. This passage, suggested by an historical statement, is based on the parting of Hector and Andromache, as given by Homer (Iliad vi. $370 \mathrm{ff}$.), with the son standing in somewhat the same relation to Carthage as Astyanax to Troy. The two accounts are not parallel, as conditions were entirely different. In framing the stories Silius drew from others to give a deeper poetical color. The words abnuis inceptis comitem (iii. 110) are an echo of Horace (Odes i. 35. 22): nec comitem abnegat, while the reference to the son (ibid. 69): Spes O Carthaginis altae| Nate, resembles Seneca (Troades 470): O gnate... spes una Phrygibus. Compare with (ibid. 145):

Quantum etenim distant a morte silentia non vitae,

the words of Horace (Odes iv. 9. 29):

Paulum sepultae distat inertiae / celata virtus.

The selection of the son as a sacrifice might be historically correct; see Justinus (xviii. 6. 12): homines ut victimas immolabant et impuberes. But Silius adds color by adapting from Lucretius (iv. $791 \mathrm{f}$.):

Quae porro haec pietas, delubra aspergere tabo?

Heu primae scelerum causae mortalibus aegris

Naturam nescire deum.

Compare also with (iv. 787):

I nunc, Ausonios ferro populare penates, the words of the Trojans in Vergil (Aeneid i. 527):

Non nos, aut ferro Libycos populare penates.

\section{THE ORATORICAL}

Only a few of the orations given by Livy are repeated by Silius, and in no other particular are there such evidences of restraint on the part of the poet. Some of the most important are omitted entirely, e.g. that of Alorcus (Livy xxi. 13), of Scipio (ibid. 40-41), and the countersetting of events by Hannibal (ibid. 43-44), of a Roman captured by Hannibal to the Roman senate (ibid. xxii. 59), 
of Torquatus in reply (ibid. 60), of Hannibal and of Scipio just before Zama (xxx. 30-31). Those of Fabius and of Scipio the Younger just before the departure of the latter to Africa are much reduced in length, though there are a few verbal touches common to both. The poet seems to have realized that the historian was the greater master of rhetorical embellishment, and, for that reason, he sought to develop equivalent rather than identical themes. This can be shown with sufficient exactness by an analysis of the harangues from the time of Hannibal's leaving Italy to the battle of Zama. According to Livy (xxx. 20. 1) Hannibal leaves Italy frendens gemensque ac vix lacrimis temperans, declaring that the Roman people had not conquered him, but the Carthaginian senate obtrectatione atque invidia. Silius distributes the parts, giving an apostrophe by Hannibal to Invidia (xvii. 189), and gemens later, when pushing his boat out to sea. The colloquy of Hannibal and Scipio before Zama (Livy xxx. $30-31$ ) is omitted, its place being taken by a talk between Juno and Jupiter. Livy (ibid. 32.6-11) has a very brief outline of the address of Hannibal to his troops, and a longer one by Scipio. He also gives (ibid. secs. 1-3), as if in the words of the actors, the importance of the battle: Certamen, non in unum diem sed in perpetuum, si felicitas adesset, victores. Roma an Carthago iura gentibus daret, ante crastinam noctem scituros; neque enim Africam aut Italiam, sed orbem terrarum victoriae praemium fore. Silius does equally as well (xvii. $387 \mathrm{ff}$.):

. . . . Non alio graviores tempore vidit

Aut populos tellus, aut, qui patria arma moverent,

Maioris certare duces. Discriminis alta

In medio merces, quicquid tegit undique caelum.

\section{ADAPTATIONS OF LUCAN's "PhARSALIA"}

The use of proper names in the metrical technique of the Latin poets is an interesting feature, and to this Silius is no exception. With the number of vowels and diphthongs, and of consonants, an unlimited number of names might have been coined which would have satisfied metrical requirements. His resemblance to Lucan is noticeable not only in his transferences, but also in his adaptations. Acoreus appears several times in Silius as Aconteus. Amanus, the mountain, Caicus and Sicoris, rivers, and Castalius, of the fountain, appear in 
Silius as men, and in the same metrical position. The same is true of the name Harpe. Lucan tells a story of Antaeus (iv. 590), while Silius mentions an Antaeus (iii. 263):

Herculeam factis servans ac nomine famam.

Some nouns are used with modifiers in the same order, as tellus Aegyptia, Anienis ad undas, vagus Afer, corniger Ammon, nauticus clamor. In some passages the same order is preserved, but with slight variation in form or in words used. The following are illustrations, with the Silian passage first: (viii. 614) Sicula . . . . ab Aetna: (i. 545) Siculae .... Aetnae; (x. 177) saxificae . . . Medusae: (ix. 670) saxificam ... Medusam.

Others are in reverse order: (viii. 458) nebulis humentibus: (vi. 369) umentis nebulas; (xiv. 579) spirantis . . . Enceladi: (vi. 294) Encelado spirante; and in equivalent combinations: (i. 587) Thracius hos Boreas: (i. 389) Boreas cum Thracius; (iii. 197) Imbriferamque hiemem permixta grandine torquet: (ix. 455) imbriferam . . . . nubem contorto pulvere nubem; (iii. 470) adesi fragmina montis: (iii. 493) magnae fragmine molis; (vii. 154) cum bucina noctem divideret: (ii. 689) ne bucina dividat horas; (xii. 673) natarent stagna cruore: (vii. 728) arva natare sanguine; (xvi. 134) iam iamque modestior armis: (viii. 476) fractisque modestior annis; (xiv. 291) levitate Sicana: (iii. 303) Graia levitate.

Although Silius and Lucan agree in the use of the derived adjective or nouns, there seems to be a designed variation in (iii. 322) stagna Tritonidos alta paludis, and (ix. 347) Tritonos . . . . paludem. Notice also (iv. 769) Thoanteae Dianae, and (i. 446) Scythicae . . . . Dianae, although Flaccus (viii. 208) has Thoanteae in the same metrical position. Numerous other passages indicate that Silius had in mind certain words of Lucan and reproduced them as written, or varied in such a way as to show clearly the source from which he drew: (viii. 647) Allia fastis: (vii. 409) Allia ripis; (viii. 390) scopulosi verticis Anxur: (iii. 84) praecipitis . . . Anxuris arces; (xvii. 489) glaciemque Aquilonibus actam: (v. 720) nudas Aquilonibus undas; (xiii. 894) Erebique cavis se . . . umbris: (vi. 731) saevis Erebi . . . flagellis; (iii. 249) undosa cretus Berenicide miles: (ix. 525) ardentem tepida Berenicida Lepti; (iv. 439) atro stimulat Bellona 
flagello: (vii. 568) Sanguineum veluti quatiens Bellona flagellum; (viii. 631) Terruerunt pavidos accensa Ceraunia nautas: (v. 652) scopulosa Ceraunia nautae | summa timent; (iii. 340) Celtae sociati nomen Hiberis: (iv. 10) Celtae miscentes nomen Hiberis; (viii. 363) tepidoque fovent Almone Cybelen: (i. 600) lotam parvo revocant Almone Cybeben; (ii. 59) Phorcynidos antra Medusae: (ix. 626) Phorcynidos arva Medusae; (viii. $451 \mathrm{ff}$.) Narque, albescentibus undis | in Thybrim properans ... . illabitur amne... . laetis Mevania pratis, and also (vi. 383) Tiberino allabimur amni: (i. 473) tauriferis ubi se Mevania campis . . qua Nar Tiberino inlabitur amni; (iii. 494) Mixtus Athos Tauro Rhodopeque adiuncta Mimanti: (vii. 450) nemus Rhodopes pinusque Mimantis. Similar to these, but combining noun with adjective forms, are (xi. 508) Aufidus . . . mox fluctus ferit Hadriacos: (ii. 407) Adriacas qui verberat Aufidus undas; (xv. 157) Ionium Aegaeo miscet mare: $(1,103)$ Ionium Aegaeo franget mare. With these we place (xiii. 355) Eoa luxum irritantia gemma: (ix. 516) Eois splendent donaria gemmis.

A considerable number of adjectives can be fairly considered as indicating use of Lucan by Silius. Some of these really belong outside of the sphere of the actors in Silius, as Cleoneus with leo in both, Gangeticus, Hyblaeus, Idalius, Idumaeus, Lagaeus, Niloticus, Nysaeus, Palaestinus, Pellaeus, Pelusiacus, Pelopeus, Pharius, Phocaeus, Rhodopeius, Rhoeteus, Salaminiacus and Smyrnaeus. Others within the sphere of the actors are used in similar logical connections, or metrical position: (viii. 602) tellure .... Euganea: (vii. 192) Euganeo . . . . colle; (ii. 64) nullaque levis Gaetulus habena: (iv. 678) semperque paratus | inculto Gaetulus equo; Illyris, Libys, Libyssus, Marmaricus, Nasamon, Sardous, and (xiv. 256)

Tauromenitana cernunt de sede Charybdim

and (iv. 461)

Tauromenitanam vincunt fervore Charybdim.

Compare the sounds in the following ending of lines: (xiii. 465) Acherontis adire and (xii. 126; xiii. 271) Acherontis ad undas with (iii. 16) Acherontis adusti. Austris is preceded by participles in Silius: (vi. 321) stridentibus, (xii. 374) fumantibus; in Lucan: (iii. 68) cessantibus; (iii. 523) tenentibus. 
The elements considered may be taken as a part of the rhetorical phases of the poem. These words of learned length and thundering sound must be considered in their relation to the recitals given by Silius; see Pliny $E p$. iii. 7. 5. They indicate the closeness with which Silius must have worked over the poem of Lucan in order to accumulate such a mass of details. But in addition to these, there are more than three hundred passages of varying length in which there is a resemblance between the two poets. Considering the question of utilization settled by the references already given, we shall quote only a few salient examples out of the mass collected. Some of the adaptations retain the corresponding words in practically the same order, as in i. 181: vi. 821:

Increpitat dominique crucem clamore reposcit:

Stat voltu maestus tacito mortemque reposcit;

i. 314 : i. 229:

Hic crebram fundit Baliari verbere glandem:

Impiger; it torto Balearis verbere fundae;

ii. 319 : x. 135 :

Nondum signatae flava lanugine malae:

Vix ulla fuscante tamen lanugine malas.; iv. 408: i. 188:

Ipsam turrigero portantem vertice muros:

Turrigero canos effundens vertice crines.

The same order is also retained in shorter groups of words, as in (i. 510) ni displicet aemula virtus: (i. 120) stimulos dedit aemula virtus; (vi. 587) vivacis dura senectae: (ii. 65) vivacia fata senectae; (vii. 198) festas . . . palmite mensas: (ii. 123) festae rorantia mensae; (viii. 534) Poeno non pervia Nola: (vi. 645) Phoebo non pervia taxus; (xiii. 109: iii. 455): stellatis axibus agger.

Generally there is some variation in the order of corresponding terms, at times the complete reversal of some, as xi. 610: i. 288:

Dum malus obtrectat facta immortalia livor:

Livor edax tibi cuncta negat, gentesque subactas; 
x. 435: vii. 149 :

Aegide Gorgoneos virgo succincta furores:

Pallas Gorgoneos diffudit in Aegida crines; vi. 545 : v. 369 :

Patientia cunctos | haec superat currus:

Vicit patientia saevi | spem ducis.

Some other illustrations of variation in statement are: (i. 29) caput urbibus alte | exserere: (v. 598) ab Oceano caput exserit Atlanteo; (vii. 245) amplexu fortuna fovet: (v. 735) fovet amplexu Cornelia; (x. 557) claro perfundit lumine campos: (vii. 215) totos perfudit lumine colles; (xvii. 535) sperans ingentia, Poenus: (vi. 796) ausosque ingentia Gracchos.

\section{METRICAL TECHNIQUE}

The same endings for adjectives and nouns in like cases of the same declension made it impossible to prevent a certain amount of alliteration in Latin. However, this was something that Silius did not seek to avoid, as is shown by lines containing words of his own creation, e.g. i. 437 :

Iamque Hostum Rutulumque Pholum ingentemque Metiscum

Iam Lygdum Duriumque simul flavumque Galaesum.

Notice the $a$ 's in xvii. 155 :

Nec mora: propulsa sulcant vada salsa carina, and the possible rhyming:

Mixta minis et torva trucis responsa senatus [xi. 121];

Romuleis durastis, ait, succedere muris [xi. 75];

Quos fugitis socios? quosve additis? ille ego sanguis [xi. 177];

Tum solum Decius Capuae decus. Isque receptus [xi. 158];

Nec crinem Assyrio perfundere pugnet amomo [xi. 402].

This sameness of ending is most noticeable at the beginning and the ending of lines, about one line in every twenty having an example as: (iv. 156) Ex auro . . . . metallo; (ibid. 199) Teutalus . . . . tellus; (ibid. 223) Indutos . . . . Faliscos; (i. 37) Turbanti . . . paranti; (ii. 54) Effundunt .... vertunt; (ibid. 160) Ille Iubam . . . Micipsam. There are also instances, not a few, in which words rhyme, 
within alternate lines, as: (ii. $96 \mathrm{f}$.) Ille vagam caelo. . . . Ille procul campo; (x. 408) Utque diem. . . . Atque idem; (xi. 427) Nec luxus ullus. . . . Campanis modus; (ibid. 525) Quin et magnanimum. . . . Strage super socium; (ibid. 134) Et Poenos in tecta vocant. . . . . Sidonii iuvenes celebrant. Notice also the following groups: (ii. 555) Haec bello vacuos. . . . . Lugebat thalamos. . . . . . Clara genus. . . . Cui voltus; and (xi. 467) Immemor et dulcis. ... . Non mota volucris. . . . Cognita terrenae. . . . Ad puppim sacrae.

Especially noticeable are the end rhymes, either in successive or in alternate lines, e.g.: (viii. 361 f.) Bruti, Tusci; (ibid. 373 f.) sagittis . . . . cristis. Two sets of rhymes are not infrequent, as: (iv. $224 \mathrm{ff}$.) muris, Catilli, rivis, Casini; (ix. 130 ff.) acerbis, ora, nobis, reporta; (x. $482 \mathrm{ff.}$ ) bella, fando, castra, Etrusco; (xiv. $510 \mathrm{ff}$.) tuto, petebas, undas, busto; (ibid. $537 \mathrm{ff}$.) ductus, remum, unum, victus. Notice the same rhyming with proper names: (iii. $597 \mathrm{ff}$.) Thylen, lucos, Afros, Idymen; (vii. 596 ff.) senecta, secunda, Arsen, Mahalcen, nomen, Adherben. Rhyme in three alternate lines is also found, as: (xvii. $63 \mathrm{ff}$.) refusas .... per auras ... . per aras.

The beginning of lines is also stressed by alliterative devices. Particles as hic, iam, and nunc, as well as relative and demonstrative pronouns, are not infrequently repeated. But of more interest are the lines beginning with the same letter, either successively or alternately. Notice: (xiv. $525 \mathrm{ff}$.) Ac, Avehere, Aetnaeo, Atque, and (xii. 295 ff.) At, Eventus, Allato, Erigitur, Ante, Dum, Dat; (i. 359 ff.) Ad, Haec, Attonito, Haec; (ii. 512-21) Ipsaque, Inde. . . . Invadit, Immittitque, Implicat. . . . Insperatus. . . . It ; (xiv. $641 \mathrm{ff}$. ) Totque, Totum, Tum, Tot. These are extreme illustrations, yet they show the lengths to which initial stress is carried. Everywhere are examples, e.g. at a random opening of Silius: (vii. $439 \mathrm{ff}$.) Arguta, Audivit. . . . Tum, Tempora. . . Si, Si, Stat. . . . De, Dumque. Not less noticeable is the similar use of successive consonants, either in regular or reversed order: (xv. $254 \mathrm{ff}$.) Tum, Sanguine, Hic, Ille; (ibid. 287 f.) Emathio, Fervebat; (ibid. 308 f.) Oeneasque, Promittens; (ibid. 326 f.) Feminea, Exin. This method in its extremes produces some curious results, as in the succession: (iv. 390) Ultima, Virbius, Xanthippus; and the omission of $r$ from the following: (xiv. 
328 ff.) Qui, Sustulerant, Per, Tanta, Ut; and (ibid. 476) Progeniem. ... Oryntos, Qualis, Transigitur.

The chiastic arrangement of words is far less common, as:

Iamque Ebusus Phoenissa movet, movet Arbacus arma [iii. 362]; Fert Boreas Eurusque refert molem profundi [iv. 322]; At postremus Atlas, Durius postremus in orbem [xvi. 401].

At times a word ending a line is repeated at the beginning of the next, e.g.: (ii. 323) vidi |Vidi; (iv. 107) idem | Idem; (i. 201) Athlas | Athlas. Verbs are sometimes at the beginning and at the end of successive lines, as: (vi. 239) Cedebant .... premebat; (vii. 634) Venerat . . . . ferebat; (viii. 618) Ignosset . . . . videret.

If the work of Silius had been the sole survivor of Latin epic poetry it would be held in more esteem. Though he brought together much of the best that was in Latin description, yet take from the Punica all that is historical and all that is suggested and there would be little left. His characters are largely the characters of others with enough change in portrayal to relieve him of the charge of plagiarism, even while retaining enough similarity in development to suggest the source from which he drew. His judgment in selection is generally good, though at times his picture has no special relevancy. Vergil (Aeneid x. 782) closes a little history of seven lines with these words:

Sternitur infelix alieno vulnere caelumque

Aspicit et dulcis moriens reminiscitur Argos.

This apparently suggested the episode of Mopsus and his two sons (ii. 89-147), who, fato ductante, had come to Saguntum, and who, as Silius puts it,

Paenitet heu sero dulcis liquisse penates.

Here too, as another illustration, may be placed the story of Diomede, perfectly appropriate for Vergil (Aeneid xi. 253-93), but in Silius (xiii. 36-78) it has little interest.

Silius seems to have kept constantly in mind the needs of the declaimer and made the most of alliterative devices. Besides this, he was free in the use of words of learned length, as Adyrmachidae, Gradivicola, Neptunicola, Arganthoniacus, Garamanticus, Polydamanteus, Pygmalioneus, Tartessiacus. Of his seeking to arouse interest by verbal transformations one might well apply the words of Ovid (Metam. i. 1): fert animus mutatas dicere formas. As illustrations 
take: (vii. 390) nosce Fabios certamine ab uno, and (i. 612) recti sacra cupido, neither of which needs a tag. Other metamorphoses of the words of Vergil, as: (i. 642) quantus crescit in armis, for (xi. 283) quantus in clipeum adsurgat, are interesting chiefly as indications of the power of a memory which had grasped such a multitude of verbal details. But he was interested as much in the history of Livy and the rhetoric of Lucan as in the poesy of Vergil, and blended their colors with a free hand, as (vii. 524):

$$
\text { ... . disiecto Minuci vecordia vallo }
$$

Perdendi simul et perundi ardebat amore,

the first part of which gives the experience of Caesar at Pharsalia, according to Lucan (vii. 332), while the last is from Livy (Praef. 12). Other elements from other poets are utilized in the same way, all indicative of wondrous care. Pliny contrasted the latter, cura, with ingenio, but Silius might have found for himself an incomparable characterization in the words of Horace (Odes iv. $2.27 \mathrm{ff}$.):

.... Ego apis Matinae

More modoque

Grata carpentis thyma per laborem

Plurimum circa nemus uvidique

Tiburis ripas operosa parvus

Carmina fingo.

VANDERBILT UNIVERSITY

Nashville, Tenn. 